(C) 2002 The Chemical Society of Japan

\title{
カーボン粉末上に析出した水酸化ニッケルの電気化学的な還元と 水素吸蔵合金負極の新しい活性化方法への応用
}

\author{
(2001年 10 月 15 日受理)
}

森下真也**磯貝嘉宏 ${ }^{\dagger} \cdot$ 伊東一彦・砥綿真一・阿部勝司

水酸化ニッケル $(\mathrm{II})$ の析出したカーボン粉末 $\left[\mathrm{Ni}(\mathrm{OH})_{2} / \mathrm{C}\right]$ をカソード分極後, $\mathrm{X}$ 線回折, 磁気測定 ならびに TEM 観察を行った. カーボン粉末の表面に析出した水酸化ニッケル (II)の $1.4 \%$ 以が電気 化学的に還元されて金属ニッケル微粒子を生成した. 生成したニッケル微粒子が充放電反応の活性点と して作用するため, $\mathrm{Ni}(\mathrm{OH})_{2} / \mathrm{C}$ の添加によって水素吸蔵合金負極の初期活性化が促進された.

\section{1 はじめに}

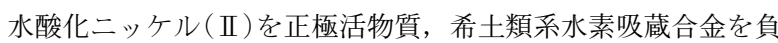
極活物質とするニッケルー水素電池は, 体積エネルギー密度なら びに出力密度が高く, 環境への負荷が少ないことから, 小型電子 機器やハイブリッド車用の電源として幅広く使用されている1)-4).

負極が所定の放電容量を示すには充放電を繰り返す必要があ り, 水素吸蔵合金の活性化がこの電池の課題の一つとなってい る．水素吸蔵合金の活性化方法として，アルカリ5)，酸6) あるい は水蒸気(7)による合金表面の改質のほか，合金表面にパラジウム をめっきする8)，あるいは合金粉末とニッケル粉末とを混合する 万法9) ${ }^{90)}$ が報告されている. ニッケル粉末を用いる活性化方法で は，二ッケル粉末表面の酸化物層を水素還元することによって水 素吸蔵合金の初期活性化はさらに促進されたが，還元したニッケ ル粉末の再酸化の抑制が課題であった.

金属イオンの還元電位を見てみると, 初充電後の負極の電位は パラジウム, ニッケルなどの水素解離触媒として作用する金属イ オンを還元し, 再酸化されることなく金属の状態を維持させるこ とが可能である ${ }^{11)}$. 著者らは, この点に着目し, 導電性のある カーボン上にこれらの金属イオンを吸着させ, 電気化学的に還元 して金属微粒子を生成する新しい活性化添加材の可能性を検討し てきた ${ }^{12)}$. そして, カーボン粉末表面へのニッケルイオンの種 々の保持方法を検討する過程で, 水酸化ニッケル $($ II $)$ が析出した カーボン粉末 [以後, $\mathrm{Ni}(\mathrm{OH})_{2} / \mathrm{C}$ とする]では, カソード分極に よって析出した水酸化ニッケル (II)の一部が電気化学的に還元さ れてニッケル微粒子を生成することが明らかとなった。

本報告では, カーボン粉末の表面に析出した水酸化ニッケル (II)の電気化学的な還元現象ならびに $\mathrm{Ni}(\mathrm{OH})_{2} / \mathrm{C}$ を水素吸蔵合 金の新しい活性化添加材として検討した結果を述べる.

株式会社豊田中央研究所，480-1192 愛知県長久手町大 字長湫字横道 41-1

†株式会社豊田自動織機，448-8671 刈谷市豊田町 2-1

\section{2 実験}

\section{$2.1 \mathrm{Ni}(\mathrm{OH})_{2} / \mathrm{C}$ の作製}

使用した $\mathrm{Ni}(\mathrm{OH})_{2} / \mathrm{C}$ は，以下に示す手順にて作製した。

1) $0.9 \mathrm{~g}$ の Cabot 社製カーボンブラック ( VULCAN $\mathrm{XC72R}$ ，一次粒子 =約 $30 \mathrm{~nm}$ ) を $200 \mathrm{~mL}$ の蒸留水に加え，ホモ ジナイザー(Ika 社製，T-25)を用いて分散させた.

2) $0.03 \mathrm{M}\left(\mathrm{M}=\mathrm{mol} \mathrm{dm}^{-3}\right)$ の硝酸ニッケル溶液を $140 \mathrm{~mL}$ 添 加して, 1 時間攪汼した。

3) $\mathrm{pH} \geqq 9$ となるまで $0.06 \mathrm{M}$ の水酸化ナトリウム溶液を滴下 し,さらに 1 時間攪拌した.

4) 蒸留水を加えながら, 数回, 加圧沪過し, 乾燥後, ミル 粉砕した.

また，カーボン粉末に対するニッケルイオンの吸着量を求める ため，3）の操作（アルカリ溶液の滴下による中和）を省略した カーボン粉末 (以後, $\mathrm{Ni}^{2}+/ \mathrm{C}$ とする) も作製した.

\section{$2.2 \mathrm{Ni}(\mathrm{OH})_{2} / \mathrm{C}$ の解析}

2.2.1 ニッケル量 : テフロン製の密閉容器を用いて熱濃硫酸/ 硝酸に $\mathrm{Ni}^{2+} / \mathrm{C}$ あるいは $\mathrm{Ni}(\mathrm{OH})_{2} / \mathrm{C}$ を溶解し, 高周波プラズマ 発光分析装置(島津製作所製, ICPS-2000)にてカーボン粉末中の ニッケル量を測定した。

2.2.2X 線回折 : $\mathrm{Ni}(\mathrm{OH})_{2} / \mathrm{C}$ と 2 質量\%のメチルセルロース 水溶液とを混練し, 集電体 $(30 \mathrm{~mm} \times 40 \mathrm{~mm}, t=1.6 \mathrm{~mm})$ である 住友電工製の発泡ニッケル (セルメット＃ 7 , 多孔率 $=96 \%$, 孔 径 $=200-300 \mu \mathrm{m})$ に均一に充填した。乾燥後, 加圧成形し, 電 池の電解液を模擬した $5 \mathrm{M}$ の水酸化カリウムと $1 \mathrm{M}$ の水酸化リ チウムからなる水溶液に浸漬すると同時に酸化水銀電極 (以後, $\mathrm{Hg} / \mathrm{HgO}$ と略)に対して $-0.9 \mathrm{~V}$ の電位に保持した. 2 時間の力 ソード分極後, イオン交換水中で超音波を印加して $\mathrm{Ni}(\mathrm{OH})_{2} / \mathrm{C}$ を回収し, 乾燥してX 線回折測定 (理学電機製, RU-200Z)を行 った.

2.2.3 磁気測定：カソード分極後の $\mathrm{Ni}(\mathrm{OH})_{2} / \mathrm{C}$ をよく混合 した後, $50 \mathrm{mg}$ をはかり取ってアクリル樹脂製の試料容器に充媜 
した，振動試料型磁力計(東英工業製，VSM-3S）を用い，室温に て土約 $19 \mathrm{kOe}$ の範囲で磁場掃印して $\mathrm{Ni}(\mathrm{OH})_{2} / \mathrm{C}$ の磁化曲線を 測定した。磁場 $= \pm 10 \mathrm{kOe}$ に抢ける接線を内挿し，この 2 本の 平行線間の距離から飽和磁化を算出した.

2.2.4 TEM : カーボン粉末上に析出した水酸化ニッケル (II) の形態を検討するため, 透過電子顕微鏡 (日本電子製, JEM$200 \mathrm{EX} I I)$ にてカソード分極後の $\mathrm{Ni}(\mathrm{OH})_{2} / \mathrm{C}$ を観察した.

\section{3 電池特性の評価}

2.3.1 試作電池: 水素吸蔵合金を構成するニッケル, コバル ト，アルミニウム，マンガン，ランタン，セリウム，ネオジムな らびにプラセオジム(高純度化学研究所製, 純度 $=99.9 \%$ )の所定 量をはかり取り，プラズマボタン溶解炉にて合金インゴット（Table 1) を作製した. 真空 (約 $1 \times 10^{-3} \mathrm{~Pa}$ ) 中で $1000{ }^{\circ} \mathrm{C}$ にて 8 時 間均一化処理した後, 機械的に粉碎, 分級して $75 \mu \mathrm{m}$ 以下の合 金粉末とした.

水素吸蔵合金粉末と 2.0 質量 $\%$ $\mathrm{Ni}(\mathrm{OH})_{2} / \mathrm{C}$ とを機械的に混 合後, 2 質量\%のメチルセルロース水溶液と混練して活物質ペー ストとした，発泡二ッケル集電体 $(30 \mathrm{~mm} \times 40 \mathrm{~mm}, t=1.6 \mathrm{~mm})$ に均一に充填, 乾燥後, 加圧成形して負極(放電容量 : 約 700 $\mathrm{mA} \mathrm{h}$ ) とした．正極には，三元(ニッケル，コバルト，亜鉛)系の 水酸化二ッケル極(放電容量: 約 $1200 \mathrm{~mA} \mathrm{~h}$ ) を使用し， 2 枚の正 極間にポリエチレン・ポリプロピレン製のセパレーターを介して 負極をはさむ負極容量規制のニッケルー水素電池を作製した。電 解液には, $1 \mathrm{M}$ の水酸化リチウムと $5 \mathrm{M}$ の水酸化カリウムから なる水溶液を使用した。

2.3.2 充放電試験および複素インピーダンス測定 : 作製した 電池を用いて $20^{\circ} \mathrm{C}$ の恒温槽内で以下に示す手順にてサイクルご とに負極の放電容量と複素インピーダンスを測定した。

1) $0.2 \mathrm{C}(1 \mathrm{C}=$ 負極容量を 1 時間で充電もしくは放電する電 流値 $\left.{ }^{13)}\right)$ で 6 時間充電後, 10 時間以上静置した.

$2 ）$ 負極電位 $\left(E_{0}\right)$ を測定後, インピーダンスアナライザー (Solartron 社製，1250/1286)を用いて負極電位を高周波数側(64 $\mathrm{kHz})$ から低周波数側 $(0.01 \mathrm{~Hz})$ にかけて $E_{0}$ を中心に $5 \mathrm{mV}$ 振動 させ，同期した電流変化から負極の複素インピーダンスを求めた。

3） $0.2 \mathrm{C}$ で正極・負極間の電圧が $0.8 \mathrm{~V}$ となるまで放電後, 電池を 1 時間以上静置した.

4）負極の放電容量がほほ一定の值となるまで1)－3）を繰り 返した。

得られた複素インピーダンススペクトルには, 既報10112)14) と同 じ解析を行った。

Table 1 Chemical composition of hydrogen storage alloy

\begin{tabular}{cc}
\hline Element & Content $/$ mass\% \\
\hline $\mathrm{La}$ & 14.7 \\
$\mathrm{Ce}$ & 9.8 \\
$\mathrm{Pr}$ & 1.9 \\
$\mathrm{Nd}$ & 7.3 \\
$\mathrm{Ni}$ & 50.6 \\
$\mathrm{Co}$ & 9.9 \\
$\mathrm{Mn}$ & 3.9 \\
$\mathrm{Al}$ & 1.9 \\
\hline
\end{tabular}

\section{3 結果および考察}

$3.1 \mathrm{Ni}(\mathrm{OH})_{2} / \mathrm{C}$

3.1.1 ニッケル含有量 : $\mathrm{Ni}^{2+} / \mathrm{C}$ ならびに $\mathrm{Ni}(\mathrm{OH})_{2} / \mathrm{C}$ に含ま れるニッケル量を高周波プラズマ発光分析法にて求めた結果を Table 2 に示す. $\mathrm{Ni}^{2+} / \mathrm{C}$ 中のニッケル量は検出限界以下であ り，カーボン粉末に対するニッケルイオンの吸着量は非常に少な かった。一方, $\mathrm{Ni}(\mathrm{OH})_{2} / \mathrm{C}$ からは 18.8 質量\%のニッケルが検出 され，作製時に加えたニッケルイオンのほぼ全量が水酸化ニッケ ルとしてカーボン粉末上に析出していた．カーボン粉末に対する ニッケルイオンの吸着量が非常に少ないことから，カーボン表面 にニッケルイオンを多量に保持するのに水酸化物として析出させ ることが有効であった。

3.1.2 XRD: 次に, 水素を吸蔵した水素吸蔵合金の電位にほ ほ等しい $-0.9 \mathrm{~V} v \mathrm{~s} . \mathrm{Hg} / \mathrm{HgO}$ に 2 時間保持した $\mathrm{Ni}(\mathrm{OH})_{2} / \mathrm{C}$ に ついてX 線回折測定を行った (Fig. 1)．得られた X 線回折パ ターンには, 水酸化ニッケルの回折線のほか, ブロードながら金 属ニッケルの回折線が認められた．回折線の半価幅から Scherrer の式15)をもとに計算すると，析出したニッケルの粒径は約 4 $\mathrm{nm}$ と見積もられた。一方, カソード分極前の $\mathrm{Ni}(\mathrm{OH})_{2} / \mathrm{C}$ から は金属二ッケルの回折線が認められなかったことから, カーボン 粉末上に水酸化ニッケルとして担持されたニッケルイオンの一部 が何らかのかたちで電気化学的に還元されてニッケル微粒子とな ったと考えられる.

3.1.3 磁気測定 : カソード分極後の $\mathrm{Ni}(\mathrm{OH})_{2} / \mathrm{C}$ の磁化曲線 をFig. 2 に示す. 磁場 $= \pm 10 \mathrm{kOe}$ にて内插した接線より，強磁 性成分であるニッケルの飽和磁化は $0.14 \mathrm{emu} \mathrm{g}^{-1}$ と算出され た. 強磁性体において粒径が磁区よりも小さくなると, 熱運動の 影響によって飽和磁化の值が小さくなる現象 (超常磁性) が知られ ている ${ }^{16)}$. 生成したニッケル微粒子も粒径が非常に小さいこと から，超常磁性を示していると考えられる．そのため, ニッケル 微粒子の生成量を正確に求めることはできないが、ニッケルバル ク材の飽和磁化の值 ( $\left.54.4 \mathrm{emu} \mathrm{g}^{-1}\right)$ より，少なくとも 0.26 質量 $\%$ の金属二ッケル微粒子が生成したと推定された。超音波を用い

Table 2 Nickel content of samples

\begin{tabular}{cc}
\hline Sample & Nickel content $/$ mass $\%$ \\
\hline $\mathrm{Ni}^{2+} / \mathrm{C}$ & $0.01>$ \\
$\mathrm{Ni}(\mathrm{OH})_{2} / \mathrm{C}$ & 18.8 \\
\hline
\end{tabular}

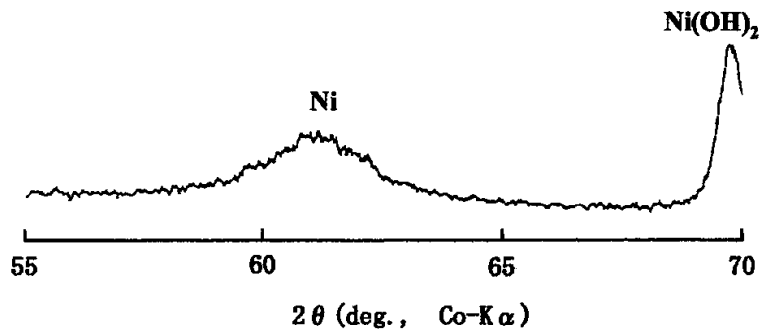

Fig. 1 XRD pattern of $\mathrm{Ni}(\mathrm{OH})_{2} / \mathrm{C}$ after cathodic polarization. 
て $\mathrm{Ni}(\mathrm{OH})_{2} / \mathrm{C}$ を回収した際にカーボン粉末から析出した水酸化 ニッケルの一部が脱落した可能性もあるが，析出した水酸化ニッ ケルの少なくとも $1.4 \%$ が電気化学的に還元されたと考えられる.

$3.1 .4 \mathrm{TEM}$ : カソード分極後の $\mathrm{Ni}(\mathrm{OH})_{2} / \mathrm{C}$ の TEM 写真を Fig. 3 に示す. カーボンの一次粒子上に複数の微細な棒状の水酸 化ニッケル (幅: 約 $5 \mathrm{~nm}$, 長さ: 約 $35 \mathrm{~nm}$ )が析出していた. カ ソード分極後のパラジウムイオンを吸着したカーボン粉末では, 金属パラジウムの微粒子がカーボン粉末表面に存在した ${ }^{12)}$. し かし, 今回のサンプルではカーボンの一次粒子上にニッケル微粒 子は認められなかった.

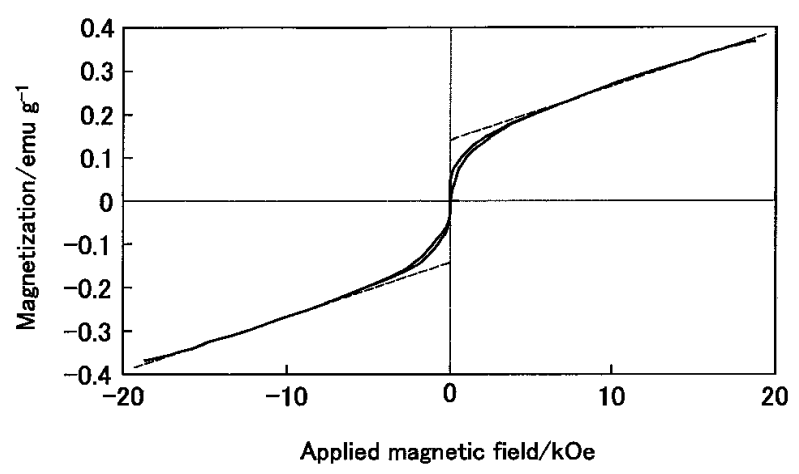

Fig. 2 Magnetization loop of $\mathrm{Ni}(\mathrm{OH})_{2} / \mathrm{C}$ after cathodic polarization.

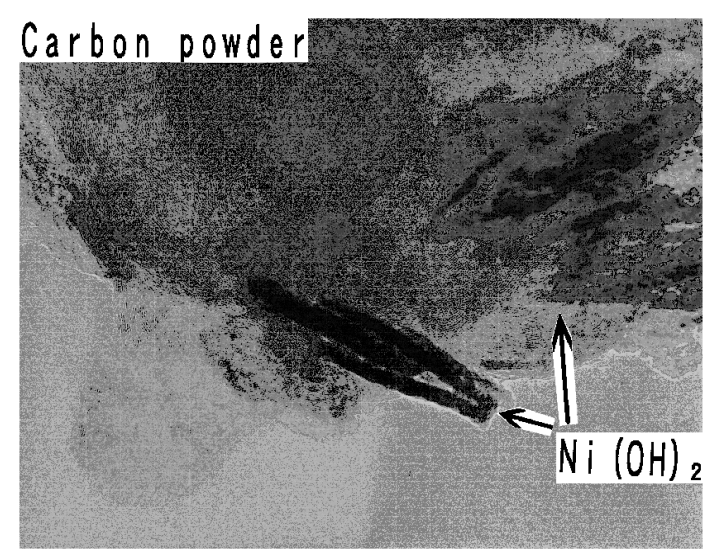

Fig. 3 TEM image of $\mathrm{Ni}(\mathrm{OH})_{2} / \mathrm{C}$ after cathodic polarization.
3.1 .5 ニッケルの還元機構 : カーボン粉末上にニッケル微粒 子が生成する機構として以下の二つが考えられる(Fig. 4).

a) 析出した水酸化ニッケルのカーボン粉末との接触部におい て固相状態の水酸化ニッケルの一部がカソード分極によって電気 化学的に還元された.

b) 化学平衡的には強アルカリ水溶液中においてニッケルイ オンは溶解可能な電位範囲 $\left(\mathrm{pH} 14\right.$, ニッケルイオン濃度 $=10^{-5}$ $\mathrm{M}$ として約 $-0.84-0.04 \mathrm{~V} v \mathrm{~s} . \mathrm{Hg} / \mathrm{HgO}$ )がある ${ }^{17)}$. 水酸化ニッ ケルの導電性が極めて低い18)ため, カソード分極時においても 水酸化ニッケルの先端部分は設定電位よりも貴な電位となり, こ の部分でニッケルイオンが溶解して近傍のカーボン粉末上で還元 された. 現時点においてニッケル微粒子の生成機構の詳細は明ら かではないが，TEM 観察においてカーボン粉末上にニッケル微 粒子が認められないことから, a)の可能性が高いと考えている.

\section{2 活性化添加材への応用}

カーボン粉末との接触部において析出した水酸化ニッケルの一 部が還元され，ニッケル微粒子が形成されるとすると，生成した ニッケル微粒子の表面近傍には電気的な接触が不十分なために還 元されなかった水酸化ニッケルが残存する可能性がある. その場 合には，二ッケル微粒子表面と電解液との接触が不十分で, $\mathrm{H}_{2} \mathrm{O}$ との間の電子移動反応に対する触媒効果が十分に発揮されないこ とが懸念される．そこで，この点を明らかにするため, $\mathrm{Ni}(\mathrm{OH})_{2}$ /C を添加した負極をもとに負極容量規制のニッケルー水素電池を 作製して初期活性化特性ならびに放電容量と電荷移動抵抗との関 係を検討した。

3.2.1 初期活性化特性 : 水素吸蔵合金のみ, あるいは水素吸 蔵合金と $\mathrm{Ni}(\mathrm{OH})_{2} / \mathrm{C}$ とを混合してから作製した負極の放電容量 とサイクル数との関係を Fig. 5 に示す.負極の放電容量は $\mathrm{Ni}(\mathrm{OH})_{2} / \mathrm{C}$ の添加によって増加しており, $\mathrm{Ni}(\mathrm{OH})_{2} / \mathrm{C}$ による初 期活性化の促進効果が認められた.

3.2 .2 放電容量 vs. 電荷移動抵抗 : 初期活性化過程に抢ける 水素吸蔵合金 $1 \mathrm{~g}$ 当たりに換算した放電容量と電荷移動抵抗 $\left(R_{\mathrm{ct}}\right)$ との関係を Fig. 6 に示す. $R_{\mathrm{ct}}$ の值が小さくなるにつれて 合金 $1 \mathrm{~g}$ 当たりの放電容量は増加しており，負極の活性化は合金 表面での電子移動反応の起きやすさによってほぼ決まっていた. また, 同一サイクル数で比較すると, $R_{\mathrm{ct}}$ の值は $\mathrm{Ni}(\mathrm{OH})_{2} / \mathrm{C}$ の 添加によって小さくなっており, $\mathrm{Ni}(\mathrm{OH})_{2} / \mathrm{C}$ が水素吸蔵合金負 極の活性化添加材として作用することが確認された.

水素還元したニッケル粉末を用いても水素吸蔵合金は活性化さ れたが，負極作製時に還元されたニッケル粉末が大気中の酸素に a)

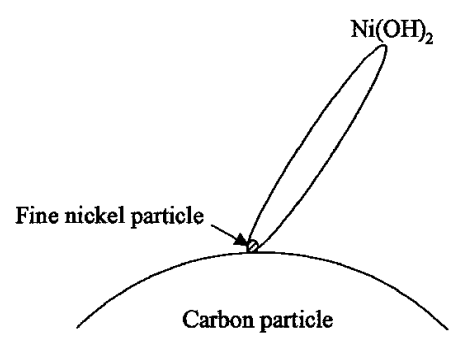

b)

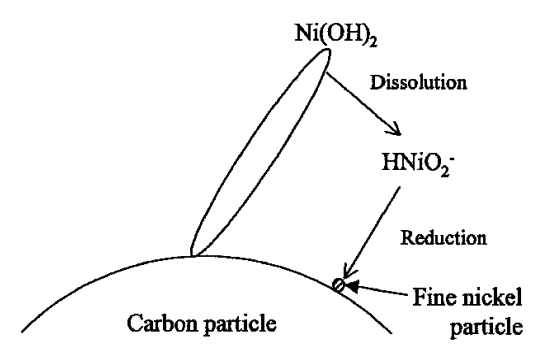

Fig. 4 Plausible paths for formation of fine nickel particles: a) direct reduction model, b) dissolution-reduction model. 


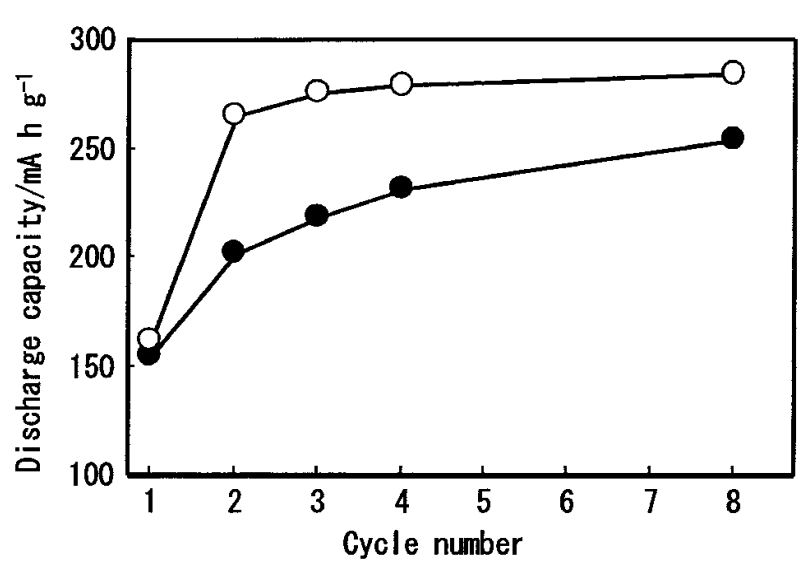

Fig. 5 Plots of discharge capacity $v$ s. cycle number of negative electrodes. 0 : Hydrogen storage alloy, $\bigcirc$ : hydrogen storage alloy +2 mass $\% \mathrm{Ni}(\mathrm{OH})_{2} / \mathrm{C}$.

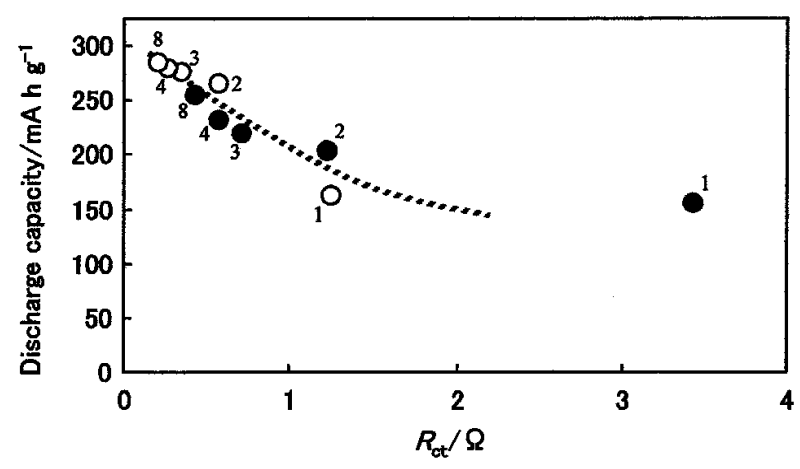

Fig. 6 Plots of discharge capacity vs. charge transfer resistance $\left(R_{\mathrm{ct}}\right)$ of the negative electrodes. Numerals in the plots are charge/discharge cycle number. Each symbol corresponds to the same one in Fig. 5.

よって酸化されやすく，時に発火するという問題があった，その 点, 今回検討した $\mathrm{Ni}(\mathrm{OH})_{2} / \mathrm{C}$ では電池作製後の初充電時にニッ ケル微粒子が生成するため, 水素吸蔵合金負極の安全な活性化添 加材と考えられる.

$$
4 \text { ま と め }
$$

$\mathrm{Ni}(\mathrm{OH})_{2} / \mathrm{C}$ の電気化学的な還元現象ならびに水素吸蔵合金負
極に対する添加効果を検討し，以下の結果を得た.

1) $-0.9 \mathrm{~V} v$ v. $\mathrm{Hg} / \mathrm{HgO}$ に 2 時間保持した $\mathrm{Ni}(\mathrm{OH})_{2} / \mathrm{C}$ から は, 金属ニッケルの微粒子が認められた.

2) ニッケル微粒子の粒径は約 $4 \mathrm{~nm}$ で, カーボン粉末上に析 出した水酸化ニッケルの $1.4 \%$ 以上が還元されたと見積られた.

3） カーボン粉末との接触部に抢ける水酸化ニッケルの電気 化学的な還元によってニッケル微粒子が生成している可能性が高 いと推定された.

4) $\mathrm{Ni}(\mathrm{OH})_{2} / \mathrm{C}$ の添加によって水素吸蔵合金負極の初期活性 化が促進され, 生成するニッケル微粒子が充放電反応の活性点と して作用した.

1）野上光造，古川修弘，日化， 1995, 1.

2) 石川 博, 化学と工業, 49, 1633(1996).

3）松田宏夢, 生駒宗久, 電気化学, 65, 96(1997).

4) 田村英雄監修, “電子とイオンの機能化学シリーズ, Vol. 1 ，いま注目されているニッケルー水素二次電池のすべ て”，エヌ・ティー・エス，東京(2001).

5) 生駒宗久, 高橋 収, 坪井良二, 松本 功, 電気化学, 61, 972(1993).

6) 押谷政彦, 松村勇一, 日本金属学会主催シンポジウム, $\mathrm{Ni}$ 水素電池用水素吸蔵合金の将来展望, 1995,21 .

7）山川俊輔, 砥綿真一, 斎藤克史, 日比野繁徳, 黒田光太 郎, 坂 公恭, 日本金属学会第 125 回講演概要, 1999, 127.

8) T. Kitamura, C. Iwakura, H. Tamura, Electrochimica. Acta, 27, 1729 (1982).

9) P. J. Kalal, L. M. Timberg, V. A. Ettel, Electrochemical Society Proceedings, 96-14, 202 (1996).

10）森下真也, 深作博史, 大矢 豊, 砥綿真一, 阿部勝司, 日化， 2000, 451 .

11）境 哲男, 表面技術， 45, 581(1994).

12）森下真也, 藤田勝義, 伊東一彦, 砥綿真一, 阿部勝司, 日化, 2000, 773 .

13）電気化学編集委員会, 電気化学, 61, 981(1993).

14）森下真也, 磯貝嘉宏, 大矢 豊, 砥綿真一, 阿部勝司, 日化, 1999, 791.

15) B. D. Cullity, "Elements of X-Ray Diffraction", AddisonWesley (1956), Chap. 3 ; 松村源太郎訳, “X 線回折要論 ,，第 3 章，アグネ (1961).

16) 近角聡信, 大田恵造, 安達健五, 津屋 昇, 石川義和編, “磁性体ハンドブック”, 朝倉書店(1975), pp. 905-907, p. 1167.

17) M. Pourbaix, "Atlas of Electrochemical Equilibria in Aqueous Solutions”, National Association of Corrosion Engineers (1974), Chap. IV.

18) R. Barnard, C. F. Randell, F. L. Tye, J. Appl. Electrochem., 10, 127 (1980). 


\title{
Electrochemical Reduction of Nickel (II) Hydroxide Deposited on Carbon \\ Powder and Application to a New Activation Method for Hydrogen Storage Alloy Negative Electrodes
}

\author{
Shinya MorishitA*, Yoshihiro Isogat ${ }^{\dagger}$, Kazuhiko IToH, \\ Shin-ichi Towata and Katsushi ABE \\ Toyota Central Research and Development Laboratories, Inc.; 41-1 Yokomichi, \\ Nagakute, Aichi 480-1192 Japan \\ ${ }^{\dagger}$ Toyota Industries Corporation; 2-1 Toyoda-cho, Kariya-shi 448-8671 Japan
}

After cathodic polarization, nickel (II) hydroxide-deposited carbon powder $\left[\mathrm{Ni}(\mathrm{OH})_{2} / \mathrm{C}\right]$ was investigated by XRD, magnetism measurement, and TEM observation. More than $1.4 \%$ of the nickel(II) hydroxide deposited on the surface of the carbon powder was electrochemically reduced and fine nickel particles were formed. Since the fine nickel particles act as active sites for charge/discharge reactions, the initial activation of hydrogen storage alloy negative electrodes was promoted by adding $\mathrm{Ni}(\mathrm{OH})_{2} / \mathrm{C}$. 